\title{
Socioeconomic and clinical profile of pregnant women with Gestational Hypertension Syndrome
}

\author{
Perfil socioeconômico e clínico de gestantes com Síndrome Hipertensiva Gestacional
}

Joseline Pereira Lima ${ }^{1}$, Laiza Larissa do Nascimento Veras², Évelin Karla Félix da Silva Pedrosa ${ }^{2}$, Giselle dos Santos Costa Oliveira', Maria Vilani Cavalcante Guedes ${ }^{1}$

Objective: to know the socioeconomic and clinical profile of pregnant women with Gestational Hypertensive Syndrome. Methods: descriptive and exploratory study, carried out in Primary Care, with 50 pregnant women, using form. Data analyzed by descriptive statistics. For dichotomous questions a binomial test was used. Results: pregnant women aged between 18 and 35 years (76.0\%), married (52.0\%), housewife (44.0\%), with high school education $(64.0 \%)$, non-smokers $(88.0 \%)$ and non-alcoholic $(96.0 \%)$ predominated. They had never had an abortion (68.0\%), had previous cesarean deliveries (37.0\%), Diabetes Mellitus (24.0\%), chronic Hypertension $(60.0 \%)$, and were heart disease patients $(6.0 \%)$, overweight $(56.0 \%)$ and had bleeding during pregnancy $(12.0 \%)$. Conclusion: young pregnant women of childbearing age prevailed with high school education and other comorbidities and important risk factors.

Descriptors: Nursing; Women's Health; Hypertension, Pregnancy-Induced.

Objetivo: conhecer o perfil socioeconômico e clínico de gestantes com Síndrome Hipertensiva Gestacional. Métodos: estudo descritivo e exploratório, realizado na Atenção Básica, com 50 gestantes, mediante formulário. Dados analisados pela estatística descritiva. Realização de teste binomial para questões dicotômicas. Resultados: predominaram gestantes com idades entre 18 e 35 anos (76,0\%), casadas (52,0\%), dona de casa (44,0\%), com ensino médio completo $(64,0 \%)$, não fumante $(88,0 \%)$ e não etilista $(96,0 \%)$. Nunca abortaram $(68,0 \%)$, fizeram cesáreas antecedentes $(37,0 \%)$, portadoras de Diabetes Mellitus $(24,0 \%)$, Hipertensão arterial crônica $(60,0 \%)$, cardiopatas (6,0\%), acima do peso (56,0\%) e hemorragia durante a gestação $(12,0 \%)$. Conclusão: prevaleceram gestantes jovens, em idade fértil, com escolaridade de nível médio e associação de outras comorbidades e fatores de risco importantes.

Descritores: Enfermagem; Saúde da Mulher; Hipertensão Induzida pela Gravidez.

\footnotetext{
${ }^{1}$ Universidade Estadual do Ceará. Fortaleza, CE, Brazil.

${ }^{2}$ Faculdade de Enfermagem Nova Esperança de Mossoró. Mossoró, RN, Brazil. 


\section{Introduction}

Gestation is one of the most expected moments in the lives of many women, but some conditions can complicate and compromise this period. There are many diseases that can occur during pregnancy, reflecting, in a damaging way, the health of the maternal-fetal binomial ${ }^{(1)}$. It is important that the pregnant woman is aware of certain factors, such as obesity, age, daily habits, diet and some diseases, such as hypertensive syndromes, which is a worrying problem.

Hypertension in pregnancy is also called Gestational Hypertensive Syndrome, whose complications increase the incidence of maternal and perinatal morbidity and mortality, and together with infections and hemorrhages, are among the three causes of maternal death in $\mathrm{Brazil}^{(2)}$. Therefore, the knowledge of the epidemiological profile of pregnant women with the syndrome favors the planning of prenatal care, the early identification of the pathology and the development of a therapeutic plan for the adequate follow-up of these pregnant women.

Preeclampsia and eclampsia are hypertensive syndromes that occur after the 20th week of gestation, from the manifestation of protein loss through urine (proteinuria), with the disappearance of symptoms until the 12th week after delivery. According to the degree of disease involvement, preeclampsia can be classified as mild or severe, which may present lower blood pressure values, such as $140 / 90 \mathrm{mmHg}$; and the severe one is usually identified from diastolic blood pressure equal to or greater than $110 \mathrm{mmHg}$, in addition to signs of hypertensive encephalopathy, proteinuria equal to or greater than $2.0 \mathrm{~g}$ in 24 hours, or by the presence of $2+$, in tests with tape urinary system, among others.

In the same perspective, eclampsia is diagnosed in women with hypertension who develop tonic-clonic seizures that are not caused by epilepsy or any other generalized convulsive disease, or coma. In addi- tion, there is preeclampsia superimposed on chronic hypertension that occurs when there is an acute elevation of blood pressure, as well as the appearance of preeclampsia in women with chronic hypertension or renal disease $\mathrm{e}^{(3)}$.

The hypertensive syndromes that occur in the gestational period affect about 6 to $8.0 \%$ of the pregnant women and can cause irreparable damage to the pregnant woman and the fetus. Because they characterize high-risk pregnancies, hypertensive syndromes deserve special attention, with specialized care, trained professionals and rigorous follow-up. Thus, the prenatal consultation should provide the necessary tools so that the pregnant woman can have normal and uneventful gestation ${ }^{(4)}$.

Thus, nursing plays an important role in the care of hypertensive pregnant women, since it is able to direct care to the main fragilities, thus improving the quality of care and, consequently, reducing the future complications caused by this problem. Thus, the study aimed to know the socioeconomic and clinical profile of pregnant women with Gestational Hypertension Syndrome.

\section{Methods}

It is a descriptive, exploratory study carried out in four Basic Health Units and a Maternal and Child Health Outpatient Clinic in a city in the northeast of Brazil, a reference in the care of high-risk pregnant women.

The population was composed of pregnant women with medical diagnosis of Gestational Hypertensive Syndrome. The study included pregnant women who met the inclusion criteria: over 18 years of age and who underwent prenatal care in the Maternal and Child Health Clinic and in Basic Health Units. Pregnant women hospitalized and without physical and psychic conditions were excluded from the study interviewer.

The sample was probabilistic, chosen in a ran- 
dom simple manner, by drawing lots from the number of pregnant women with appointments for consultations, totaling 50 hypertensive pregnant women. The data were collected from September to November, 2017, through interviews, using a form composed of objective questions. The collection was performed in a closed room, free of interruptions, after signing the Informed Consent Term.

The data were analyzed through descriptive statistics, being expressed in simple frequency and percentage, through the software Statistical Package for the Social Sciences version 17.0. In this sense, the binomial test was performed to verify the hypothesis that the Yes and No responses of the variables related to the obstetric and clinical history have the same proportion $(50.0 \%)$. Values of $\mathrm{p}<0.05$ were considered significant.

The article was approved by the Research Ethics Committee of the Nova Esperança Nursing School, according to protocol no $144 / 2012$, in compliance with ethical standards governed by Resolution 466/12.

\section{Results}

The results were divided into three parts: socioeconomic profile, obstetric and clinical history, and current gestational conditions of women with Gestational Hypertensive Syndrome. The socioeconomic profile of the pregnant women investigated is shown in Table 1.

Regarding the socioeconomic profile of the pregnant women (Table 1), it was possible to observe that the majority (76.0\%) were 18 to 34 years old, slightly more than half (52.0\%) were married; almost half $(44.0 \%)$ housewives; $64.0 \%$ with high school education; $78.0 \%$ reported family income of 1 to 3 minimum wages; and the absolute majority declared themselves to be non-smokers (88.0\%) and non-alcoholics (96.0\%).
Table 1 - Socioeconomic profile of pregnant women with Gestational Hypertensive Syndrome $(n=50)$

\begin{tabular}{lc}
\hline Variables & $\mathbf{n}(\mathbf{\%})$ \\
\hline Age (years) & $38(76.0)$ \\
$18-34$ & $12(24.0)$ \\
$>35$ & \\
Marital status & $26(52.0)$ \\
Married & $7(14.0)$ \\
Single & $17(34.0)$ \\
Stable union & \\
Occupation & $22(44.0)$ \\
Housewife & $2(4.0)$ \\
Cashier & $3(6.0)$ \\
Hairdresser & $7(14.0)$ \\
Maid & $8(16.0)$ \\
Saleswoman & $2(4.0)$ \\
Farmer & $4(2.0)$ \\
Self-employed & $2(4.0)$ \\
Manicure & \\
Schooling & $15(30.0)$ \\
Grade School & $32(64.0)$ \\
High School & $3(6.0)$ \\
University & \\
Family Income (minimal wage) & $10(20.0)$ \\
$<1$ & $39(78.0)$ \\
$1-3$ & $1(2.0)$ \\
$>4$ & \\
Smolker & $6(12.0)$ \\
Yes & $44(88.0)$ \\
No & \\
alcoholics & $2(4.0)$ \\
Yes & $48(96.0)$ \\
No &
\end{tabular}

Table 2 - Obstetric and clinical history of pregnant women with Gestational Hypertensive Syndrome $(\mathrm{n}=50)$

\begin{tabular}{lccc}
\hline \multirow{2}{*}{ Variables } & Yes & No & p \\
\cline { 2 - 4 } & $\mathbf{n ~ ( \% )}$ & $\mathbf{n ~ ( \% )}$ & \\
\hline Abortions & $16(32.0)$ & $34(68.0)$ & $0.015^{*}$ \\
Previous deliveries & $37(74.0)$ & $13(26.0)$ & $<0.001$ \\
Cesarean deliveries & $37(100.0)$ & - & - \\
Vaginal delivery & $9(29.8)$ & $26(70.2)$ & $0.006^{*}$ \\
Diabetes mellitus & $12(24.0)$ & $38(76.0)$ & $<0.001^{*}$ \\
Chronic arterial hypertension & $30(60.0)$ & $20(40.0)$ & 0.203 \\
Urinary infection & $24(48.0)$ & $26(48.0)$ & 0.888 \\
Heart disease & $3(6.0)$ & $47(94.0)$ & $<0.001^{*}$ \\
thromboembolism & - & $50(100.0)$ & - \\
Anemia & $10(20.0)$ & $40(80.0)$ & $<0.001^{*}$ \\
Difficulty getting pregnant & $9(18.0)$ & $41(82.0)$ & $<0.001^{*}$ \\
\hline *Statistical significance (p<0.05; Binomial test) & &
\end{tabular}


Regarding the clinical history (Table 2), it was observed that they did not report abortions (68.0\%), they had previously become pregnant $(74.0 \%)$, all of them undergoing cesarean deliveries and only $29.8 \%$ in previous pregnancies. Considering the clinical history, it was observed that $76.0 \%$ were non-diabetic, $60.0 \%$ had chronic hypertension, $48.0 \%$ reported urinary infection, $82.0 \%$ had no difficulty in becoming pregnant, only $6.0 \%$ were patients with heart disease, none reported thromboembolism, and $20.0 \%$ reported having anemia before the current gestation. Statistical significance was also observed for the occurrence of abortion, vaginal delivery, Diabetes Mellitus, heart disease, anemia and difficulty to conceive.

Table 3 - Conditions of the current gestation of pregnant women with Gestational Hypertensive Syndrome $(\mathrm{n}=50)$

\begin{tabular}{|c|c|}
\hline Variables & n (\%) \\
\hline \multicolumn{2}{|c|}{ Number of fetuses } \\
\hline Único & $46(92.0)$ \\
\hline Twin & $4(8.0)$ \\
\hline \multicolumn{2}{|c|}{ Nutritional status } \\
\hline Low weight & $2(4.0)$ \\
\hline Eutrophy & $20(40.0)$ \\
\hline Overweight & $28(56.0)$ \\
\hline \multicolumn{2}{|c|}{ Urinary infection } \\
\hline Yes & $19(28.0)$ \\
\hline No & $36(72.0)$ \\
\hline \multicolumn{2}{|c|}{ Gestational diabetes } \\
\hline Yes & $5(10.0)$ \\
\hline No & $45(90.0)$ \\
\hline \multicolumn{2}{|l|}{ Anemia } \\
\hline Yes & $7(14.0)$ \\
\hline No & $43(86.0)$ \\
\hline \multicolumn{2}{|c|}{ Threat of premature birth } \\
\hline Yes & $7(14.0)$ \\
\hline No & $43(86.0)$ \\
\hline \multicolumn{2}{|c|}{ Trace elements or polyhydramnios } \\
\hline Yes & - \\
\hline No & $50(100.0)$ \\
\hline \multicolumn{2}{|c|}{ Premature membrane rupture } \\
\hline Yes & - \\
\hline No & $50(100.0)$ \\
\hline \multicolumn{2}{|c|}{ Delayed intrauterine growth } \\
\hline Yes & - \\
\hline No & $50(100.0)$ \\
\hline \multicolumn{2}{|l|}{ Hemorrhage } \\
\hline Yes & $6(12.0)$ \\
\hline No & $44(88.0)$ \\
\hline
\end{tabular}

Table 3 shows the conditions of the current gestation at the time of the research, with $92.0 \%$ having single gestation, $56.0 \%$ were overweight, $28.0 \%$ reported urinary infection and $14.0 \%$ anemia. In addition, $14.0 \%$ of the pregnant women interviewed also reported having threatened preterm labor, but none reported trace elements or polyhydramnios, premature rupture of the membrane or retarded intrauterine growth. They also reported a $12.0 \%$ occurrence of bleeding.

\section{Discussion}

The method used was considered as a limitation of the study. The descriptive and exploratory design made it impossible to contribute to evidence in nursing and health. However, it is important to highlight that the results found can contribute to the nursing services, with information that can direct actions, especially during the prenatal consultation, related to care, in order to reduce the occurrence of complications caused by the Syndrome studied.

However, it is important to emphasize that of the total of 50 pregnant women, 12 (24.0\%) were over 35 years of age, being higher than the average found in the literature, around $13,0 \%{ }^{(5)}$. Women, who are 35 years of age or older are generally susceptible to adverse perinatal outcomes and maternal morbidity and mortality, being considered late pregnancies. Therefore, pregnancies in women over 35 years of age have been considered to be at high risk, mainly due to the increased incidence of hypertensive syndromes, premature rupture of membranes, presence of diabetes, and a higher chance of an Apgar score in the fifth minute be less than seven. Thus, the studies show that due to ovarian senescence and increased frequency of chronic diseases in women in this age group, as gestation is postponed, the probability of women becoming susceptible to various risks increases ${ }^{(6-7)}$.

Regarding marital status, occupation and schooling, the study corroborates the research carried out with high-risk pregnant women, which showed 
that $52.5 \%$ of the women interviewed were married, $36.1 \%$ were housewives, and $47.5 \%$ completed high school. Among these variables, the level of education deserves attention, since low level of schooling may represent a risk factor, since it is related to less access to information and limited understanding of the importance of health care $^{(8)}$.

The data related to alcohol consumption and smoking were found in a study that found $88.0 \%$ of non-alcoholic pregnant women and $93.6 \%$ who did not use tobacco ${ }^{(9)}$. Ethylene can cause a number of malformations, including typical craniofacial anomalies, growth impairment, musculoskeletal, genitourinary and cardiac alterations, dysfunction of the central nervous system, which may occur with mental deficits and behavioral disorders, which is characterized by the syndrome called Alcohol Syndrome Fetal. Smoking may be associated with obstetric complications, such as miscarriage, prematurity, ectopia, premature rupture of membranes, reduction of milk production and fetal death. If smoking is correlated with increased blood pressure, the chances of obstetric complications are considerably increased ${ }^{(10)}$.

Regarding the obstetric history of the pregnant women investigated, it was observed that $32.0 \%$ had abortion and most, previous pregnancies. Of these, all had undergone Cesarean delivery. Determining the way of delivery and the best time for this event in high-risk pregnancies represents the greatest dilemma experienced at the time. It is noteworthy that the interruption of pregnancy in pregnant women with preeclampsia can be programmed by elective cesarean section or induction of labor. The risk of complications is higher when cesarean section is performed, highlighting a greater chance of hemorrhagic complications, infections and hypertensive spikes ${ }^{(11)}$.

Relevant factors found in the study were the clinical history, that is, the presence of chronic diseases and/or infections. The onset of diabetes during pregnancy is a risk factor that favors the development of hypertensive crises. Chronic hypertension is ano- ther problem that can be observed before pregnancy, before 20 weeks of gestation or be diagnosed for the first time during pregnancy, in which it is not resolved until 12 weeks after childbirth ${ }^{(5)}$. Urinary tract infections were described as a factor that can lead to risky pregnancies, leading to important complications in the gestational and perinatal periods for the mother-child binomial ${ }^{(12)}$.

The correlation between gestation and heart disease is fundamental. In Brazil, the incidence of heart disease during pregnancy exceeds international statistics, with a rate of $4.2 \%$. In addition, in the pregnancy-puerperal cycle, universally, heart disease is considered the major cause of indirect maternal de$\operatorname{ath}^{(13)}$.

During pregnancy, the risk of venous thromboembolism increases five to ten times, and may reach 20 times in the puerperium when compared to non-pregnant women of the same age ${ }^{(14)}$. In the present study, no pregnant woman had a history of thromboembolism.

Anemia was present both as clinical and gestational history. The consequences of anemia are serious, especially during pregnancy. The incidence of anemia varies according to the characteristics of the population studied. In developing countries, anemia can be associated with nutritional problems and other diseases that potentiate it, such as gastrointestinal infections and parasitic diseases. The presence of anemia may potentiate maternal morbidity and mortality due to postpartum hemorrhage. Low levels of hemoglobin that correspond to moderate and severe anemia are associated with increased rates of maternal-fetal mortality, as well as the birth of low birth weight and prematurity infants ${ }^{(15)}$.

With regard to the current gestation, it was observed that the majority presented single gestation. Regarding nutritional status during gestation, most of the pregnant women reported being overweight. Currently, both maternal nutritional status and gestational weight gain have been the focus of several studies, 
due to the increasing prevalence of disorders, as well as the essential role of gestational outcomes. Maternal obesity influences maternal health, birth weight, gestation time and possible pre and postpartum complications $^{(16)}$.

Another relevant factor of the study was the occurrence of Gestational Diabetes. Epidemiological study has considered diabetes as a risk factor for Gestational Hypertensive Syndrome ${ }^{(17)}$. Thus, the risk factors for these disorders, in some cases, are associated in the same gestation, further compromising the course of this process. Therefore, the knowledge of these is of great relevance for the understanding of the etiological mechanism and planning of preventive measures $^{(18)}$.

In the Gestational Hypertensive Syndrome, womb/placenta insufficiency is observed, with fundamental repercussions on the newborn. Among the fetal complications, prematurity, restricted growth, premature rupture of the membrane and variations in the amount of amniotic fluid (trace elements/ polyhydramnios) ${ }^{(2)}$ are prominent. In this, seven cases of threats of preterm birth were found and none of the other complications were reported.

Another complication that deserves attention is hemorrhage. In 2011, the World Health Organization listed the five main potentially fatal obstetric complications, among which are hemorrhage, pre-eclampsia and eclampsia ${ }^{(17)}$.

\section{Conclusion}

Prevalence of young pregnant women of childbearing age with medium level schooling, in addition, there was an association of other comorbidities and important risk factors. The knowledge of the profile of pregnant women with Gestational Hypertensive Syndrome is important so that the health professionals, who work mainly in the prenatal, direct actions for the early diagnosis and the prevention of the main complications that Syndrome can cause.

\section{Collaborations}

Lima JP and Veras LLN contributed to designing and designing, analyzing and interpreting data and writing the article. Pedrosa EKFS, Oliveira GSC and Guedes MVC assisted in the writing of the article and critical review of relevant intellectual content. All authors collaborated for final approval of the version to be published.

\section{References}

1. Costa ALRR, Araújo Junior E, Lima JWO, Costa FS. Fatores de risco materno associados a necessidade de unidade de terapia intensiva neonatal. Rev Bras Ginecol Obstet. 2014; 36(1):29-34. doi: http://dx. doi.org/10.1590/S0100-72032014000100007

2. Morais FM, Novaes JM, Silveira MCA, Araújo MJAR, Melo SM, Gontijo LS. Uma revisão do perfil clínicoepidemiológico e das repercussões perinatais em portadoras de síndrome hipertensiva gestacional. Rev Eixo [Internet]. 2013 [citado 2018 abr. 23]; 2(1):69-82. Disponível em: http://revistaeixo. ifb.edu.br/index.php/RevistaEixo/article/ viewFile/103/51

3. Melo WF, Oliveira BA, Saldanha HGAC, Sousa JS, Maracaja PB. A hipertensão gestacional e o risco de pré-eclâmpsia: revisão bibliográfica. REBES [Internet]. 2015 [citado 2018 abr. 11]; 5(3):7-11. Disponível em: http://revista.gvaa. com.br/revista/index.php/REBES/article/ viewFile/3648/3288

4. Zanatelli C, Doberstein C, Girardi JP, Posser J, Beck DGS. Síndromes hipertensivas na gestação: estratégias para a redução da mortalidade materna. Rev Sau Int [Internet]. 2016 [citado 2018 abr. 5]; 9(17):73-81. Disponível em: http://local.cnecsan. edu.br/revista/index.php/saude/index

5. Gravena AAF, Paula MG, Marcon SS, Carvalho MDB, Pelloso SM. Maternal age and factors associated with perinatal outcomes. Acta Paul Enferm. 2013; 26(2):130-5. doi: http://dx.doi. org/10.1590/S0103-21002013000200005 
6. Alves NCC, Feitosa KMA, Mendes MES, Caminha MFC. Complications in pregnancy in women aged 35 or older. Rev Gaúcha Enferm. 2017; 38(4):201742. doi: http://dx.doi.org/10.1590/19831447.2017.04.2017-0042

7. Bezerra ACL, Mesquita JS, Brito MCC, Teixeira FV. Desafios enfrentados por mulheres primigestas em idade avançada. Rev Bras Ciênc Saúde. 2015; 19(2):163-8. doi: http://dx.doi.org/10.4034/ RBCS.2015.19.02.12

8. Costa LD, Cura CC, Perondi AR, França VF, Bortoloti DS. Perfil epidemiológico de gestantes de alto risco. Cogitare Enferm [Internet]. 2016 [citado 2018 jan. 17]. 21(2):1-8. Disponível em: http:// revistas.ufpr.br/cogitare/article/view/44192

9. Oliveira ACM, Graciliano NG. Hypertensive disorders of pregnancy and gestational diabetes mellitus in a public maternity hospital of a Northeastern Brazilian capital, 2013: prevalence and associated factors. Epidemiol Serv Saúde. 2015; 24(3):441451.doi:http://dx.doi.org/10.5123/S167949742015000300010

10. Lima BA, Ramalho EB, Egydio MM, Soares JM. Prevalência de fatores de risco entre gestantes do município de Ipatinga, Minas Gerais, Brasil, no ano de 2010. Braz J Surg Clin Res [Internet]. 2014 [citado 2018 fev. 02]; 6(2):34-40. Disponível em:https://www.mastereditora.com.br/ periodico/20140306_190914.pdf

11. Linhares JJ, Macêdo NMQ Arruda GM, Vasconcelos JLM, Saraiva TV, Ribeiro, AF. Fatores associados à via de parto em mulheres com pré-eclâmpsia. Rev Bras Ginecol Obstet. 2014; 36(6):25963. doi: http://dx.doi.org/10.1590/S0100720320140004812

12. Carvalho CI. Infecção do trato urinário associado a gestantes e o papel do profissional farmacêutico no tratamento farmacoterapêutico. FACIDER Rev Científ [Internet]. 2015 [citado 2018 abr. 07]. Disponível em: http://sei-cesucol.edu.br/revista/ index.php/facider/article/view/77/122
13. Martins LC, Freire CMV, Capuruçu CA, Nunes MCP, Rezende CAL. Risk Prediction of Cardiovascular Complications in Pregnant Women With Heart Disease. Arq Bras Cardiol. 2016; 106(4):289-96. doi: http://dx.doi.org/10.5935/abc.20160028

14. Oliveira ALML, Marques MA. Venous thromboembolism prophylaxis in pregnancy. J Vasc Bras. 2016; 15(4):293-301. doi: http://dx.doi. org/10.1590/1677-5449.006616

15. Townsley DM. Hematologic complications of pregnancy. Semin Hematol. 2013; 50(3):222-31. doi:http://dx.doi.org/10.1053/j.seminhematol.2013.06.004

16. Oliveira AC, Almeida LB, Lucca A, Nascimento V. Estudo da relação entre ganho de peso excessivo e desenvolvimento de diabetes mellitus e doença hipertensiva específica na gestação. J Health Sci Inst [Internet]. 2016 [citado 2018 abr 08]; 34(4):231-9. Disponível em: https://www. unip.br/presencial/comunicacao/publicacoes/ ics/edicoes/2016/04_out-dez/V34_n4_2016_ p231a239.pdf

17. Ferreira GR, Pissetti CW, Silva SR. Perfil sociodemográfico de gestantes portadoras de préeclâmpsia: estudo caso-controle. Enferm Obstétr [Internet]. 2015 [citado 2018 abr. 7]; 2(1):25-4. Disponível em: www.enfo.com.br/ojs/index.php/ EnfObst/article/download/24/26

18. Viera Neta FA, Crisóstomo VL, Castro RCMB, Pessoa SMF, Aragão MMS, Calou CGP. Review of profile and prenatal care for women with gestational diabetes mellitus. Rev Rene. 2014; 15(5):82331.doi:http://dx.doi.org/10.15253/21756783.2018193175 